\title{
THE INTERNATIONAL POLAR YEAR 2007-08 AND THE DEVELOPMENT OF PORTUGUESE RESEARCH ON ANTARCTIC PERMAFROST
}

\author{
GONÇALO VIEIRA ${ }^{1}$
}

\begin{abstract}
Portuguese Antarctic permafrost research has developed fast in the last decade. The research was initiated by the Centre for Geographical Studies of the University of Lisbon in the framework of a collaboration with the University of Alcalá (Spain) and the Spanish Antarctic Programme in 1999. In 2007 and 2008, collaborations have extended, respectively to the Bulgarian and Argentinean programmes. The critical mass has grown substantially since then and other institutions are now also involved on the research activities. The development of scientific activities was fostered by the International Polar Year 2007-08 and supported by funding from public and private institutions. A wide-scope education and outreach project has significantly contributed to the public and political awareness of the science programme, and a close interaction between scientists and society has developed. The main research topics are permafrost, active layer and geomorphological processes monitoring, with an emphasis on detection of climate change signals.
\end{abstract}

Key-words: Permafrost, active layer, Antarctic, International Polar Year.

Resumo - O Ano Polar InTERnacional 2007-08 e o DESENVOlvimento DA INVESTIGAÇÃO PORTUGUESA SOBRE PERMAFROST DA ANTÁRCTIDA. A investigação portuguesa sobre o permafrost da Antárctida desenvolveu-se rapidamente na última década. A investigação iniciou-se em 1999 através da colaboração entre o Centro de Estudos Geográficos da Universidade de Lisboa e a Universidade de Alcalá, enquadrados no Programa Antárctico Espanhol. A colaboração estendeu-se aos Programas Antárcticos Búlgaro e Argentino em 2007 e 2008, respectivamente. Desde então, a massa crítica nacional desenvolveuse rapidamente e actualmente existem outras instituições envolvidas. As actividades de investigação foram. apoiadas pelo Ano Polar Internacional 2007-08 e por diversas instituições públicas e privadas. Um plano de educação e divulgação científica, intenso e de grande amplitude, contribuiu fortemente para dar a conhecer o programa científico à classe política e ao público. Criou-se, assim, uma forte interacção entre cientistas e sociedade civil. Os principais temas de investigação são a monitorização do permafrost da camada activa e da dinâmica geomorfológica com o objectivo de detectar sinais da mudança climática.

Palavras-chave: Permafrost, camada activa, Antárctida, Ano Polar Internacional.

Recebido: 15/10/2008. Revisto: 01/06/2009. Aceite: 12/06/2009.

1 Centro de Estudos Geográficos, Universidade de Lisboa. E-mail: gtelesvieira@gmail.com 
Résumé - L'année Polaire Internationale 2007-08 et Le développement DES RECHERCHES PORTUGAISES SUR LE PERMAFROST DANS L'ANTARCTIQUE. Ces recherches ont commencé en 1999, par la collaboration entre le Centre d'Études Géographiques de l'Université de Lisbonne (Portugal) et l'Université d'Alcalá (Espagne), dans le cadre du Programme Antarctique Espagnol. Elles se sont ensuite rapidement développées. En 2007, la collaboration a inclus le Programme Antarctique Bulgare et, en 2008, le Programme Antarctique Argentin. La participation portugaise s'est élargie par la collaboration de nouvelles institutions. Ces activités scientifiques ont reçu l'aide de l'Année Polaire Internationale 2007-08 et de diverses institutions publiques et privées. La mise en marche d'un large programme d'éducation et de vulgarisation scientifiques a fortement contribué à faire connaître et comprendre ces recherches à un large public et au monde politique, en créant d'actives interactions entre société civile et chercheurs. Les principaux thèmes de recherche sont: la surveillance $d u$ permafrost, de la couche active et des processus géomorphologiques, permettant de détecter les signes de modification climatique.

Mots-clés: Permafrost, couche active, Antarctique, Année Polaire Internationale.

\section{INTRODUCTION}

The development of periglacial research among Portuguese researchers was to a large extent promoted by Suzanne Daveau $(1973,1978)$ and later by António de Brum Ferreira $(1981,1985,1993)$. Most of the research focused on the interpretation of slope deposits for their paleoenvironmental implications and only a few works have been conducted on the present-day periglacial environments of the Portuguese mountains (Vieira, 1996, Vieira, 1999, Vieira et al. 2003, 2004). Vieira e Cordeiro (1988), Ferreira et al. (2000) and Gómez Órtiz and Vieira (2006) provide overviews of the development of periglacial research in Portugal. This was the general framework when the first contacts with International Permafrost Association (IPA) were conducted in 1993, leading to the acceptance of Gonçalo Vieira in the Yellowknife Permafrost conference in 1998 as individual member and to the participation of Portuguese researchers in the Spanish conferences of the IPA (Andorra-1997, Albarracin-1999, Potes-2001, Segovia-2003 and Zaragoza/IAG-2005). The involvement with the Spanish IPA group resulted in new collaborations and was responsible for the widening of the research scope to the Antarctic. This occurred in the Spanish Antarctic campaign of 1999, following 2 years of collaboration between Miguel Ramos (University of Alcalá de Henares, Spain) and G. Vieira on ground temperature monitoring in the Serra da Estrela (Portugal). This campaign was especially important for it settled the roots for the development of contemporary permafrost research within the Portuguese science community.

\section{THE BEGGINING OF PORTUGUESE PERMAFROST RESEARCH IN THE ANTARCTIC}

The main achievements of the 1999-2000 field season were the installation of two shallow boreholes for active layer monitoring in Livingston island, the collection of meteorological data during the summer and the detailed geomorphological survey of 
NW Hurd Peninsula (fig. 1). Since then and until 2004, research was mainly related to data analysis in the framework of projects funded by the Spanish Antarctic Programme (Ramos et al, 2002; Ramos and Vieira, 2003; Vieira and Ramos, 2003).

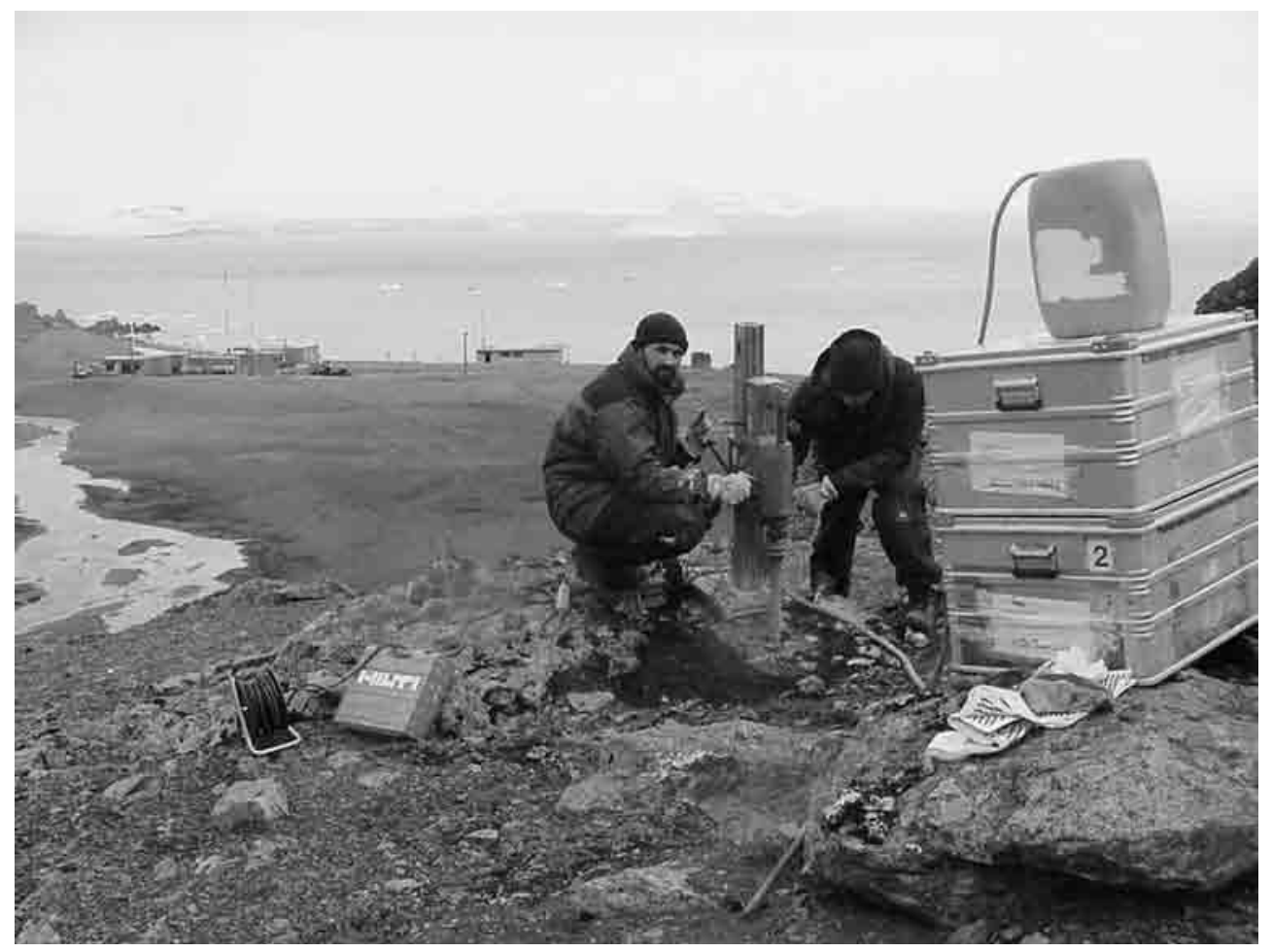

Fig. 1 - Shallow borehole drilling for active layer monitoring at Incinerador site in Livingston island in January 2000.

Fig. 1 - Perfuração para monitorização da camada activa no sítio Incinerador na ilha Livingston em Janeiro de 2000.

November 2004 was an important moment for the Antarctic permafrost research community with the participation in the National Science Foundation funded workshop on Antarctic Permafrost and Soils organized in Madison-Wisconsin (USA) by James Bockheim and the IPA. This meeting joined the main groups conducting permafrost research in the Antarctic and was the starting point for an International Polar Year 200708 (IPY) Antarctic permafrost strategy. It allowed for the identification of the major needs for the development of permafrost science in the Antarctic and two IPY projects were born: Antarctic Permafrost, Soils and Periglacial Environments (ANTPAS), led by J. Boelhouwers and J. Bockheim, and Thermal State of Permafrost, an international network of permafrost observatories (TSP), led by J. Brown.

ANTPAS aims at improving the knowledge on active layer dynamics, permafrost mapping and soils and TSP focuses on the enlargement of the network of boreholes for 
permafrost monitoring and on obtaining a global snapshot of thermal state of permafrost during the IPY. One of the key study regions is the Antarctic Peninsula where Spanish and Portuguese have a considerable knowledge on permafrost conditions. The two projects and their integration within the IPY science program provided the perfect framework for developing an Iberian joint effort on Antarctic Peninsula permafrost monitoring. Following the guidelines of the two IPY projects, the Iberian group focused on installing long-term active layer monitoring sites in the South Shetlands, as well as a network of boreholes for monitoring permafrost temperatures.

The growth of permafrost research in Portugal was recognized in 2005 by the IPA and the country was accepted as Associate Member in the $2^{\text {nd }}$ European Conference on Permafrost in Potsdam. This new status replaced the existing individual membership.

\section{THE CONSOLIDATION OF PORTUGUESE ANTARCTIC RESEARCH}

The campaign of 2005-06 marked a new stage on Portuguese permafrost research. The project PERMAMODEL lead by M. Ramos was funded by the Spanish Antarctic Programme and a team including Gonçalo Vieira, Juan José Blanco (Alcalá, Spain), Stephan Gruber (Zurich, Switzerland) and Christian Hauck (Karlsruhe, Germany) travelled to Livingston and Deception islands with two main objectives: i) geophysical surveying of terrain characteristics in order to define the best sites for borehole drilling, and ii) installation of a CALM-S site in Deception island. Geophysical surveying included an extensive campaign of electrical resistivity tomography, refraction seismics as well as ground penetration radar (e.g. Hauck et al., 2007 - fig. 2). Reina Sofia hill (275m asl) in Livingston Island and Crater Lake (90m asl) were selected as the best sites for installing the permafrost boreholes. In the later a CALM-S site was installed.

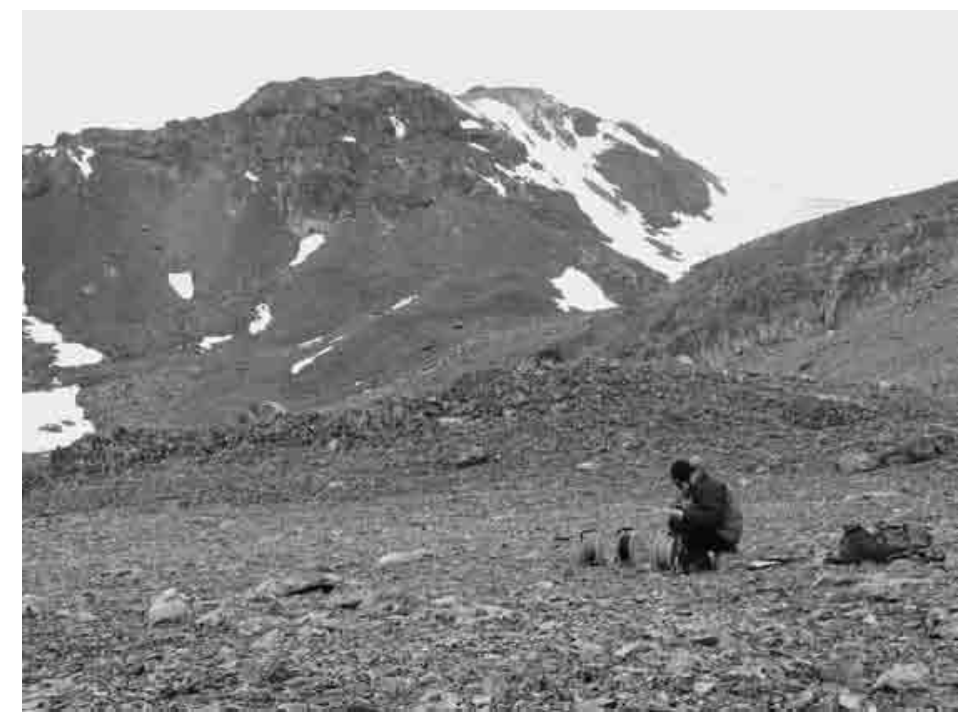

Fig. 2 - Electrical resistivity surveying in Livingston island in January 2006.

Fig. 2 - Prospeç̧ão de resistividade eléctrica na ilha Livingston em Janeiro de 2006. 
In 2006 several CEG-UL researchers constituted an ad-hoc research group that also included Bs and Ms students. This group was named GIPCA - Research Group on Antarctic Permafrost and Climate Change and was of high importance since it allowed for implementing a common strategy for the development of Antarctic research activities.

The campaign of 2006-07 was funded by the PERMAMODEL project and included the participation of Mário Neves (Univ. Lisbon) and Miguel Angel Hidalgo and David Tomé (Univ. Alcalá) in Livingston and Deception Islands integrated in the Spanish Campaign. The main objectives were: i) installing new CALM-S sites in Collado Ramos and Reina Sofia hill (Livingston Island) and upgrading the Crater Lake CALM-S site, ii) installing a series of active layer monitoring boreholes (Crater Lake, Collado Ramos and Nuevo Incinerador), and iii) installing transverse micro-erosion meter sites for monitoring the erosive action of sea-ice on coastal platforms (TMEM). In the same season, Alexandre Trindade (Univ. Lisbon) participated in the Bulgarian Antarctic campaign in St. Kliment Ohridski station, Livingston Island. This was the first first campaign in the framework of the collaboration between the CEG-UL and the Bulgarian Antarctic Institute, having developed from initial contacts in January 2006. The objective was installing a new CALM-S site in the vicinity of the Bulgarian station and initiating the continuous monitoring of active layer temperatures.

In February 2007 the IPY started with an opening ceremony organized at the Pavilion of Knowledge in Lisbon by the Portuguese IPY Committee. The event counted with the participation of the Minister for Science, Technology and Higher Education, José Mariano Gago, as well as of the President of the national science funding agency (FCT), João Sentieiro. Permafrost has been highlighted with an invited talk by J. Bockheim.

In June 2007 the Portuguese group of the IPA organized in Guarda the 1st Iberian Congress of the IPA, an event that replaced the previous Spanish IPA conferences and that takes place every 2 nd year. The conference was a success and the main results are presented in the current issue of Finisterra. Jerry Brown, President of the IPA, gave an invited talk, supporting the significance of the meeting and acknowledging its significance for the international permafrost science community.

\section{PORTUGUESE FUNDING FOR ANTARCTIC RESEARCH}

In 2007-08 the CEG-UL activities increased significantly with the maintenance of the collaboration with the Spanish and Bulgarian programmes and with the start of a new project with the Argentinean programme through a collaboration with Alberto Caselli (University of Buenos Aires). The main achievement during 2007 was obtaining for the first time national funding for the research activities. The Programa Gulbenkian Ambiente funded the project Permadrill-2007 (Permafrost drilling in the Maritime Antarctic), coordinated by G. Vieira, allowing to drill new permafrost boreholes that had been planned since 2004 (Hassler et al., 2009). The Permadrill-2007 campaign focused on drilling in Reina Sofia Hill and counted with the field participation of Vanessa Batista (Univ. Lisbon), David Tomé (Univ. Alcalá), Andreas Hassler (Univ. Zurich) and Patrick Blètry (Blètry AG drilling). There was an important logistical effort linked to this campaign, since for drilling $25 \mathrm{~m}$ deep 3 tons of equipment were needed at the drill site. The logistical support was funded by the Spanish Antarctic Programme, with the trans- 
portation of all the equipment from Europe in early September, its shipping in the Chilean ice-breaker Viel in Punta Arenas in December and the final transportation of the equipment to the top of Reina Sofia hill by helicopter in the second and final window of opportunity in late December 2007. The team arrived in January and drilled two new boreholes (25 and $15 \mathrm{~m}$ deep) near Reina Sofia hill, which were instrumented and are now important sites for the TSP programme (fig. 3). During the same campaign geophysical surveying was conducted, both in Livingston and Deception Island, as well as the maintenance and upgrading of the existing CALM-S sites. Fernando Santos (Centre of Geophysics, University of Lisbon) collaborated in the geophysical surveying campaign.

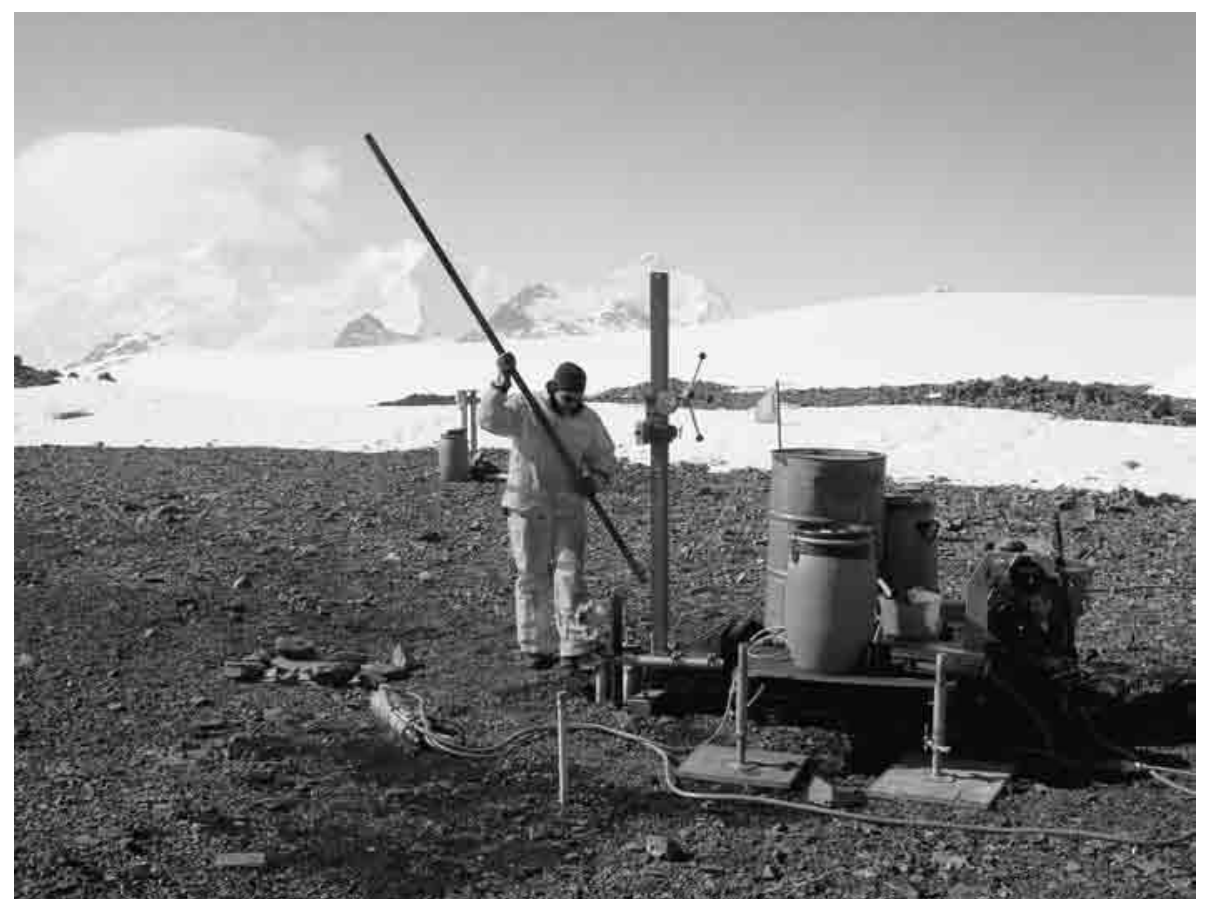

Fig. 3 - Drilling at Reina Sofia hill in Livingston island in January 2007 (photo: Vanessa Batista).

Fig. 3 - Perfuração no monte Reina Sofia na ilha Livingston em Janeiro de 2007 (fotografia: Vanessa Batista).

Together with the Bulgarian Antarctic Institute and with the support of the Fundação para a Ciência e a Tecnologia, Hilti and Honda Portugal, the project SHALLOWDRILL coordinated by G. Vieira, included the return of A. Trindade to St. Kliment Ohrdiski station. The main objective was the installation of new shallow boreholes using the lightweigth Hilti DD200 drill with diamond bit technology. The boreholes were installed near the CALM-S site in the vicinity of the Bulgarian Station and are 4 and 5 $\mathrm{m}$ deep (fig. 4). 


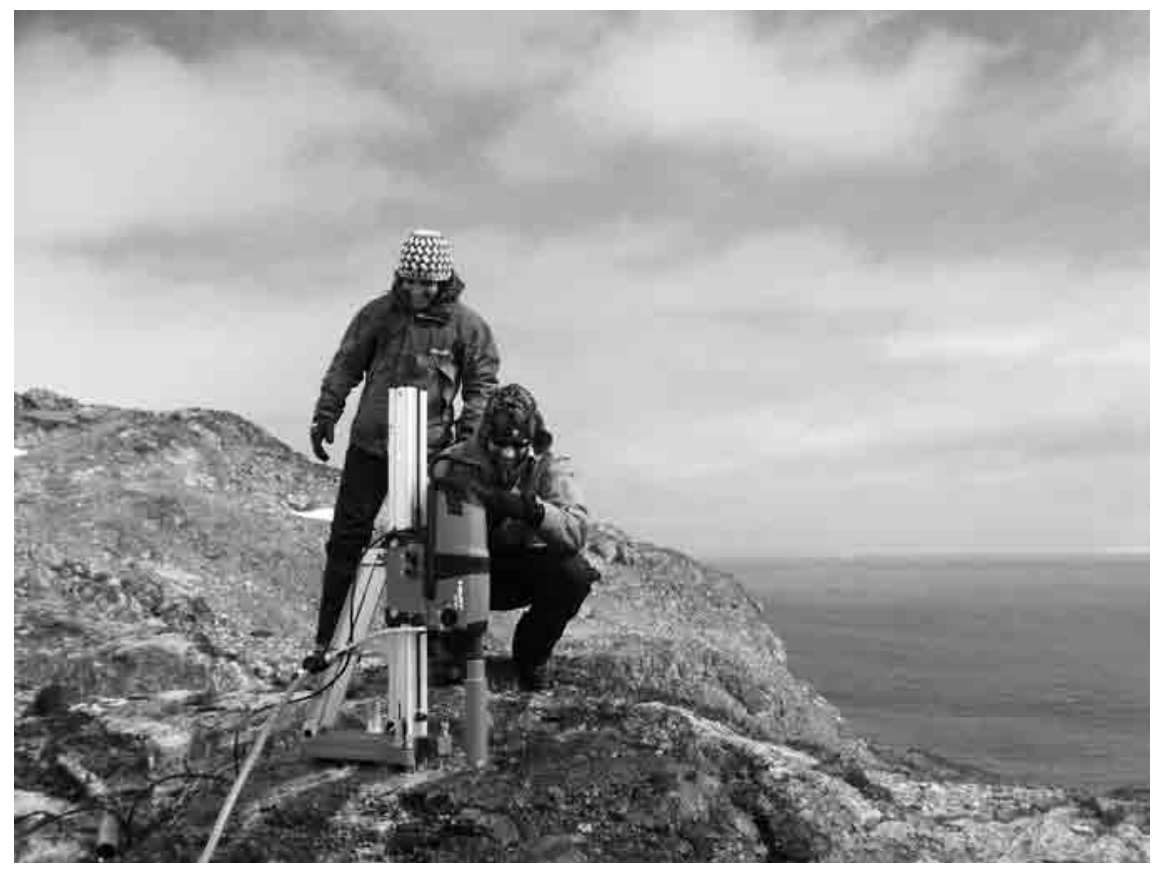

Fig. 4 - Drilling near the St. Kliment Ohridski station in January 2007 (photo: Patrick Blètry). Fig. 4 - Perfuração próximo da base St. Kliment Ohridski em Janeiro de 2007 (fotografia: Patrick Blètry).

The collaboration with the University of Buenos Aires focused on the contemporary geomorphological dynamics in Deception Island. Raquel Melo (Univ. Lisbon) participated in the Argentinean campaign together with A. Caselli and Horacio Tassone and the field work focussed on the detailed geomorphological mapping of the area between the Argentinean station Decepción and the Spanish station Gabriel de Castilla. The detailed field survey using GPS was complemented with the analysis of a high detail Quickbird image.

The success of the Portuguese Antarctic research lead in 2008 to the consolidation of GIPCA, and to its approval as a formal research group in the framework of the new CEG-UL structure, under the designation AntECC - Research Group on Antarctic Environments and Climate Change. In June 2008 the growth of Portuguese permafrost research was further recognized by the IPA and the Portuguese status at the IPA was raised to full membership at the Ninth International Conference on Permafrost in Fairbanks-Alaska. This achievement was also supported by the development of other national groups working, such as CERENA-IST on Martian geomorphology and IPIMAR on Arctic permafrost chemistry.

The campaign of 2008-09 was the first one in the framework of the Portuguese Polar Programme (ProPolar) implemented by the Portuguese Committee for the IPY and funded by the FCT in late 2007. The ProPolar funded 5 research projects from different fields that last for 2 to 3 years. Funding for permafrost research was integrated in the 
scientific area cryospheric sciences proposed by the Portuguese Committee for the IPY in 2006 as one of the strategical themes for the development of Portuguese Polar Science (Xavier et al., 2006). In this framework, the project PERMANTAR (Permafrost and Climate Change in the Maritime Antarctic), coordinated by G. Vieira, started in March 2008 with the main objective to strengthen the permafrost and active layer monitoring network in Livingston and Deception islands, and also to implement geomorphic processes monitoring sites. The campaign included the participation of G. Vieira, integrated in the Spanish campaign, with Miguel Ramos and Miguel Angel de Pablo (Univ. Alcalá) in Deception and Livingston islands; A. Trindade and António Correia (Univ. Évora) in the Bulgarian campaign in Livingston island; and V. Batista and M. Neves, with H. Tassone and Ernesto Horne (Univ. Buenos Aires) in the Argentinean campaign in Deception island. This large campaign of the CEG-UL included also a cooperation in Deception island with David Gilichinsky, Nikita Demidov and Vasili Mironov (Russian Academy of Sciences). The main achievements of this campaign were: i) an $8 \mathrm{~m}$ borehole and the installation of an automatic weather station near the Bulgarian Station, ii) three new 5m boreholes in Deception island, iii) installation of 5 geomorphic processes monitoring sites (rock glacier, solifluction and thermokarst) in Livingston and Deception islands, iv) setting up of a new CALM-S site in Irizar (Deception island), v) putting in place automatic time-lapse cameras for monitoring the snow cover and debris-flow/rock fall activity, vi) experimental installation of an electrical resistivimeter to monitor active layer evolution in Crater Lake (Deception Island), vii) electrical resistivity surveys in the vicinity of the Bulgarian station, and viii) setting up of a new TMEM site in Deception island.

\section{EDUCATION AND OUTREACH AND THE GROWTH OF PORTUGUESE PERMAFROST SCIENCE}

A significant step for the success of the strategy for the development of Portuguese permafrost research was the linkage between scientists and society, through a comprehensive education and outreach programme. The roots for these activities were tested during the Antarctic campaign of 2005-06, when G. Vieira edited a daily field blog and answered questions from students directly from the Antarctic. The activity was a success and included coverage by TV and radio broadcasting with interviews from the field on a weekly basis, and also a videoconference event with kids on RTP2. After the campaign, several permafrost talks were presented at schools, an activity which also proved to be a large success.

In June 2006 Portuguese Polar researchers of the CEG-UL and of the Centre of Marine Sciences (Univ. Algarve), together with the Association of Teachers of Geography organized a series of educational events focusing on promoting the IPY and polar science. There were a series of science activities with a focus on marine biology and also on permafrost science. These gave origin to Latitude60! Education for the Planet in the International Polar Year, a project funded by the Agência Ciência Viva that become a large success and one of the main IPY education and outreach projects worldwide. Several of the activities were permafrost related and that contributed for the acknowledgement by the public and politicians of the importance of polar science, but also of permafrost science, as one of the polar disciplines conducted by Portuguese researchers. 
The main education and outreach activities promoted in the framework of Latitude60! focusing on permafrost were the following:

- Talks by permafrost scientists in schools (from kindergarten to University level), in associations and public lectures promoted by municipalities;

- Expedition blogs updated daily from the Antarctic by permafrost scientists and young researchers;

- Activity "Ask a polar scientist" with answers from the Antarctic;

- Exhibition on five major shopping centres about the International Polar Year with an emphasis on Antarctic permafrost drilling displayed;

- Films on Portuguese permafrost research with copies available free of charge for schools and in the Internet ("Further South. Searching for the Antarctic frozen ground" and "Permafrost! Polar science at $62^{\circ} \mathrm{S}$ ");

- Field stages for high school students in the Serra da Estrela with Polar Scientists;

- Permafrost education and outreach workshops during the Polar Science Weekend, a large event at the Pavilion of Knowledge in Lisbon in 2008 that joined over 6 500 visitors;

- Scientific advising to the writers Ana Maria Magalhães and Isabel Alçada for the novel "Uma aventura no alto mar", where the heroes meet Portuguese permafrost scientists working in the Antarctic.

\section{CONCLUSION. THE CONSOLIDATION OF PORTUGUESE ANTARCTIC PERMAFROST RESEARCH}

The last decade and the IPY corresponded to an enormous increase in Portuguese permafrost research. The emphasis has been on developing the research effort, especially on monitoring permafrost and its relationship to climate change, but also on increasing the national critical mass on the subject. The strategy has been twofold: i) enlarging the number of senior researchers from different institutions of excellence (i.e. CEG-UL, CGUL and CGE); and also ii) by investing on a new generation of polar scientists. The later has been one of the main objectives of the Portuguese Committee for the IPY, not only for permafrost science, but also for other polar disciplines.

The activities mentioned in this paper benefited from public and private funding, support and from all the science-driven effort put together in the framework of the 4th International Polar Year. However, it is important to notice that this success story results also from the close linkage between outreach, education and high quality science in a marvellous environmental setting such as the Antarctic.

\section{ACKNOWLEDGEMENTS}

The advance of Portuguese research on Antarctic permafrost was the result of a direct and indirect effort of a large number of people and institutions. First of all, I would like to thank to my colleague and friend Miguel Ramos, who invited me for the Antarctic campaign of 1999-2000 and was the responsible for my Antarctic disease. I thank the full support of António de Brum Ferreira to my involvement on Antarctic research and also, to a large extent, for my background 
on periglacial geomorphology. I would like also to express my most sincere gratitude to my colleagues and students which participated in the Antarctic campaigns, contributing to the consolidation of this project: A. Trindade, A. Correia, M. Neves, R. Melo and V. Batista, as well as those that at CEG-UL more supported our work, directly or indirectly: A. Ferreira, A. Salomé, C. Mora, J. Verde, M. Fragoso, M.J. Rocha and P. Ferreira. I am grateful to Jerry Brown, past IPA President for his support in promoting our research and in getting us more involved in IPA. P. Miranda and F.Santos (CGUL) showed an early interest on the Antarctic permafrost project and got involved, providing a wider breadth to our research. Other researchers and colleagues have been important players in the development of Portuguese Antarctic permafrost research: A. Canário, A. Hassler, A. Abrahmov, A. Rocha-Campos, A. Soares, C. Hauck, C. Teixeira, D. Carlson, D. Gilichinsky, D. Tomé, E. Dutra, E. Serrano, E. Horne, G. Barriga, H. Tassone, I.l Gomes, J. Boelhouwers, J. Bockheim, J. López-Martinez, J.B. Saldanha, J.L. Zêzere, J. J. Blanco, L. Mendes-Victor, M. Hoelzle, M. Blètry, M. A.l Hidalgo, M. Angel de Pablo, M. Jarov, N. Munro, N. Demidov, P. Filipe, P. Almeida e Sousa, P. Blètry, P. Carvalho, R. Salmon, R.Bell, R. Kenderova, S. Gruber, S. Ferreira, S. Modev, V. Gomes, V. Mironov, V. Soromenho Marques and Y. Yordanov.

My gratitude is also due to José Xavier for his involvement in the IPY and for his great work in promoting Portuguese science abroad. Despite not being a permafrost scientist, he is one of the big names in the IPY and has contributed significantly for the consolidation of our group.

The Spanish Antarctic Programme has been a key element in the success of Portuguese Antarctic permafrost research and gave full support to our joint activities with the University of Alcalá. Thanks are due to Manuel Catalán, Margarita Yela and Miguel Angel Ojeda. Christo Pimpirev (Bulgarian Antarctic Institute) opened us the doors of the Bulgarian Antarctic Station and enabled the development of a strong collaboration between Portugal and Bulgaria and A. Caselli (University of Buenos Aires) has been responsible for our integration in the Argentinean Antarctic Campaigns and for the collaboration on volcanism and permafrost that has developed since then.

João Sentieiro's (FCT) direct involvement and support to our group activities and to IPY Portugal has been crucial, as well as Isabel Mendonça de Carvalho, a key liaison element at the FCT. Ana Noronha, Rosália Vargas (Ciência Viva) and António Gomes da Costa (Pavilhão do Conhecimento) gave us important suggestions and provided the resources needed for the success of our education and outreach programme.

The Fundação para a Ciência e a Tecnologia (MCTES) funded and supported widely the Portuguese IPY Committee and also permafrost research, through science projects, the FACC and grants. The Agência Ciência Viva funded the project Latitude60!. The Programa Gulbenkian Ambiente funded the project PERMADRILL-2007. Hilti Portugal offered drilling equipment and Honda Portugal a power generator. Caixa Geral de Depósitos funded two grants included in the 6-grant package "New Generation of Polar Scientists - Caixa Carbono Zero".

The Parque Natural da Serra da Estrela and especially F. Matos and M. Paz Moura, together with the Municipality of Guarda and the Centro de Estudos Ibéricos supported the organization of the $1^{\text {st }}$ Iberian Conference of the IPA

Finally, to my family I have no words to express my gratitude. They have had an infinite patience and fully supported my involvement in the very long process of the IPY lasting for almost 5-years. Sebastião, Matias and Carla: thanks for everything!

FACC-FCT funded the travel expenses of Portuguese researchers in the campaigns of 1999-00, 2005-06, 2006-07, 2007-08 and 2008-09, as well as part of the equipment in the campaign 2007-08. The drilling in 2007-08 was funded by project PERMADRILL (Programa Gulbenkian Ambiente). The Antarctic campaign of 2008-09 was funded by the FCT project PERMANTAR 
(PTDC/CLI/70020/2006). Education and outreach project Latitude60! was funded by Agência Ciência Viva, FEDER and POCI 2010.

\section{REFERENCES}

Daveau S (1978) Le périglaciaire d'altitude au Portugal. Colloque sur le périglaciaire d'altitude du domaine méditerranéen et ses abords, Estrasburgo: 63-78.

Daveau S (1973) Quelques exemples d'évolution quaternaire des versants au Portugal. Finisterra Revista Portuguesa de Geografia, VIII(15): 5-47.

Ferreira A B (1993) Manifestações geomorfológicas glaciárias e periglaciárias em Portugal. In Carvalho G S, Ferreira A B, Senna-Martínez J C (Eds.) O Quaternário em Portugal: balanço e perspectivas. A.P.E.Q., Ed. Colibri: 75-84.

Ferreira A B (1985) Influência de climas frios na morfogénese quaternária da região a norte de Lisboa. Actas da I Reunião do Quaternário Ibérico, Lisboa, I: 85-103.

Ferreira A B (1981) Manifestações periglaciárias de altitude na ilha da Madeira. Finisterra - Revista Portuguesa de Geografia, XVI(32): 213-229.

Ferreira A B, Rodrigues M L, Vieira G T (2000) Manifestações herdadas e actuais de climas frios em Portugal. In Peña Monné J L, Sánchez Fabre M, Lozano Tena M V (Eds.) Procesos y formas periglaciares en la montaña mediterránea. Teruel: 161-190.Gómez Órtiz, A.; Vieira, G. La investigación en geomorfologia glaciar en España y Portugal. Finisterra - Revista Portuguesa de Geografia, 82: 119-137.

Hauck C, Vieira G, Gruber S, Blanco J J, Ramos M (2007) Geophysical identification of permafrost in Livingston Island, Maritime Antarctic. Journal of Geophysical Research, 112: F02S19, doi:10.1029/2006JF000544.

Ramos M, Hassler A, Vieira G, Hauck C, Gruber S (2009) Setting up boreholes for permafrost thermal monitoring on Livingston Island in the Maritime Antarctic. Permafrost and Periglacial Processes, 20: 57-64. DOI: 10.1002/ppp.635.

Ramos M, Vieira G (2003) Active layer and permafrost monitoring in Livingston Island, Antarctic. First results from 2000 and 2001. In Phillips M, Springman S M, Arenson L U (Eds.) Permafrost. Proceedings of the Eight International Conference on Permafrost, 21-25 July 2003, Zurich, Switzerland, Balkema - Swets \& Zeitlinger, Lisse: 929-933.

Ramos M, Vieira G, Crespo F, Bretón L (2002) Seguimiento de la evolución temporal del gradiente térmico de capa activa en las proximidades de la B.A.E. Juan Carlos I (Antártida). In Serrano E, García A (Eds.) Periglaciarismo en montaña y altas latitudes. Dep. Geografia, Univ. Valladolid: 257-276.

Vieira G T (1999) Coarse sand accumulations in granite mountains: the case-studies of the Serra do Gerês and Serra da Estrela (Portugal). Zeitschrift für Geomorphologie, Suppl.-Bd., 119: 105-118.

Vieira G T (1996) A acção dos pipkrakes na morfogénese actual na Serra do Gerês. Finisterra - Revista Portuguesa de Geografia, XXXI(61): 3-28.

Vieira G T, Cordeiro A M R (1998) Geomorfologia periglaciária em Portugal: estado do conhecimento. In Gómez Órtiz A, Salvador Franch F, Schulte L, García Navarro A (Eds.) Procesos biofisicos actuales en medios frios. Estudios recientes, Publ. Universitat de Barcelona, Barcelona: 347-371.

Vieira G, Ramos M (2003) Geographic factors and geocryological activity in Livingston Island, Antarctic. Preliminary results. In Phillips M, Springman S M, Arenson L U (Eds.) Permafrost. 
Proceedings of the Eight International Conference on Permafrost, 21-25 July 2003, Zurich, Switzerland, Balkema - Swets \& Zeitlinger, Lisse: 1183-1188.

Vieira G, Mora C, Gouveia M M (2004) Oblique rainfall and contemporary geomorphological dynamics (Serra da Estrela, Portugal). Hydrological Processes, 18: 807-824.

Vieira G, Mora C, Ramos M (2003) Ground temperature regimes and geomorphological implications in a Mediterranean mountain (Serra da Estrela, Portugal). Geomorphology, 52: 57-72 .

Xavier J, Vieira G, Canário A (2006) Portuguese Science Strategy for the International Polar Year. CCMAR and CEG. 